\title{
Polynyas and Ice Edge Habitats in Cultural Context: Archaeological Perspectives from Southeast Baffin Island
}

\author{
ANNE HENSHAW ${ }^{1}$
}

(Received 2 July 1999; accepted in revised form 20 February 2002)

\begin{abstract}
A combination of paleoclimatic proxies, zooarchaeological data from historic Inuit habitation sites, and Geographic Information System (GIS) studies of modern sea-ice extremes were used to track the changing size and shape in modern times of a polynya situated in outer Frobisher Bay, Baffin Island. From these data, inferences were drawn about historic Inuit settlement patterns and subsistence strategies in the region over the last 500 years. Results of the analysis show that during episodes of cooling temperatures and increased ice severity, the polynya decreases in size and is more localized in outer Frobisher Bay. During warmer periods, the polynya increases in size, extending its ice edge habitat significantly towards the head of Frobisher Bay. These findings, as well as zooarchaeological studies from the outer Bay region that show extensive use of the floe edge habitat, suggest that the present-day polynya was an important factor in attracting various migrations of people to this area, beginning as early as the 14th century. The polynya represented not only a predictable food source on which Inuit could depend during periods of high climatic variability, but also a reliable economic base that allowed them to maintain a high degree of autonomy throughout the different phases of European contact history. The findings discussed in this study are presented at two spatial scales in order to draw connections between regional patterns of sea-ice distribution and Inuit settlement and more local patterns of human response and adaptation.
\end{abstract}

Key words: historic Inuit, paleoclimate, zooarchaeology, sea ice, polynyas, Baffin Island, incremental analysis, Phoca hispida, seasonality, age determination

RÉSUMÉ. On a fait appel à une combinaison de données paléoclimatiques indirectes, de données zooarchéologiques provenant de sites d'habitations inuits historiques et d'études sur les extrêmes actuels de glace marine réalisées à l'aide d'un Système d'information géographique (SIG) afin de suivre les changements dans la dimension et la forme actuelles d'une polynie située au large de la baie Frobisher, dans l'île de Baffin. On a tiré de ces données certaines hypothèses concernant les schémas historiques de peuplement inuit et les stratégies de subsistance qui ont prévalu dans cette région au cours des derniers 500 ans. Les résultats de l'analyse montrent que, durant des épisodes de refroidissement de la température et d'augmentation de la rigueur de la glace, la polynie diminue en taille et qu'elle est localisée plus au large de la baie Frobisher. Au cours de périodes plus chaudes, la polynie augmente en taille, étendant sensiblement son habitat en bordure des glaces vers le fond de la baie. Ces résultats, joints aux études zooarchéologiques sur la région au large de la baie, qui révèlent une utilisation généralisée de l'habitat situé à la limite de dislocation, suggèrent que la polynie actuelle constituait un élément majeur dans l'attrait de la région pour diverses vagues de migration humaine, et ce, dès le XIV ${ }^{\mathrm{e}}$ siècle. La polynie représentait non seulement une source alimentaire prévisible sur laquelle les Inuits pouvaient compter durant des périodes de grandes variations climatiques, mais aussi une base économique fiable qui leur a permis de conserver un grand niveau d'autonomie tout au long des différentes phases de l'histoire du contact européen. Les résultats discutés dans cette étude sont présentés à deux échelles spatiales pour permettre l'établissement de liens à un niveau régional entre les schémas de distribution de la glace marine et de peuplement inuit, ainsi qu'à un niveau plus local entre les schémas de réaction et d'adaptation humaines.

Mots clés: Inuit historique, paléoclimat, zooarchéologie, glace marine, polynies, île de Baffin, analyse différentielle, Phoca hispida, caractère saisonnier, mesure des temps

Traduit pour la revue Arctic par Nésida Loyer.

\section{INTRODUCTION}

One of the great challenges in tracing the dynamic relationship between climate and culture is finding ways to understand the impact of global climatic phenomenon at scales relevant to human activity. Until recently, many studies examining climate/culture interaction in the Arctic used broad global climatic indicators to explain regional and sometimes local archaeological phenomena (McGhee, 1969/70, 1972; Dekin, 1972; Fitzhugh, 1972; Schledermann, 1976; Barry et al., 1977; Maxwell, 1985). The climate record and culture sequence were often placed side by side, but no specific cause-and-effect relationships were demonstrated, and social factors were given a low

${ }^{1}$ Coastal Studies Center, Bowdoin College, 7000 College Station, Brunswick, Maine 04011-8470, U.S.A.; ahenshaw@bowdoin.edu

(C) The Arctic Institute of North America 
profile. Some of the explanatory problems associated with such weak correlations have been identified in the literature (McGhee, 1981; Fitzhugh and Lamb, 1985; McGovern, 1991). Few studies, however, have attempted to create holistic, multilinear models that can portray climatic linkages more explicitly and interpret them in a broader social, economic, and political context. Instead of creating a dichotomy between the environmental and social forces behind culture change, we need to examine such factors together to achieve a holistic interpretation of past events.

Studies that have been moving in this direction include McGovern's (1991) re-examination of the Norse collapse and extinction on Greenland, as well as Kaplan and Woollett's (2000) re-analysis of the Labrador communal house phenomenon. Research examining historic Inuit populations in outer Frobisher Bay, Baffin Island, employed a similar approach to help explain the cultural continuity that persisted in this area despite changing social and environmental conditions over the last 500 years (Henshaw, 1999, 2000). Specifically, the latter studies showed that historic Inuit in the area, ethnographically identified as the Nugumiut by Boas (1964), enjoyed a great deal of economic autonomy and political independence during several phases of colonial expansion into the eastern Canadian Arctic. In part, Nugumiut were able to maintain this autonomy because of their marginal position relative to European centers of activity and through their own social mechanisms that reinforced intra-group cohesion (Henshaw, 1999). But this explanation provides only a partial understanding of what attracted Inuit to this area in the first place and what role (if any) the environment played in shaping the history that unfolded.

This paper examines the environmental context of Inuit autonomy during a rapid period of social, economic, and climatic change by linking high-resolution paleoclimatic reconstructions of changing sea-ice conditions and polynya formation with historic Inuit settlement and subsistence over the last 500 years. For Nugumiut, as for other Arctic maritime-adapted peoples in the circumpolar world, the culture/climate relationship is dictated in large part by sea ice. Sea ice is a dominant part of the northern environmental seascape for most of the calendar year. It greatly influences the nature of transportation in both summer and winter, and its concentration on a seasonal basis has direct links with the distribution of marine mammals and sea birds on which Inuit, as hunters, depend to meet their socioeconomic needs. Within this sea-ice environment, polynyas and associated ice-edge habitats form an important source of biological productivity.

\section{POLYNYA FORMATION AND BIOLOGICAL PRODUCTIVITY}

Polynyas are generally defined as nonlinear areas of open water surrounded by ice. They vary greatly in size and shape and appear to be caused by a combination of

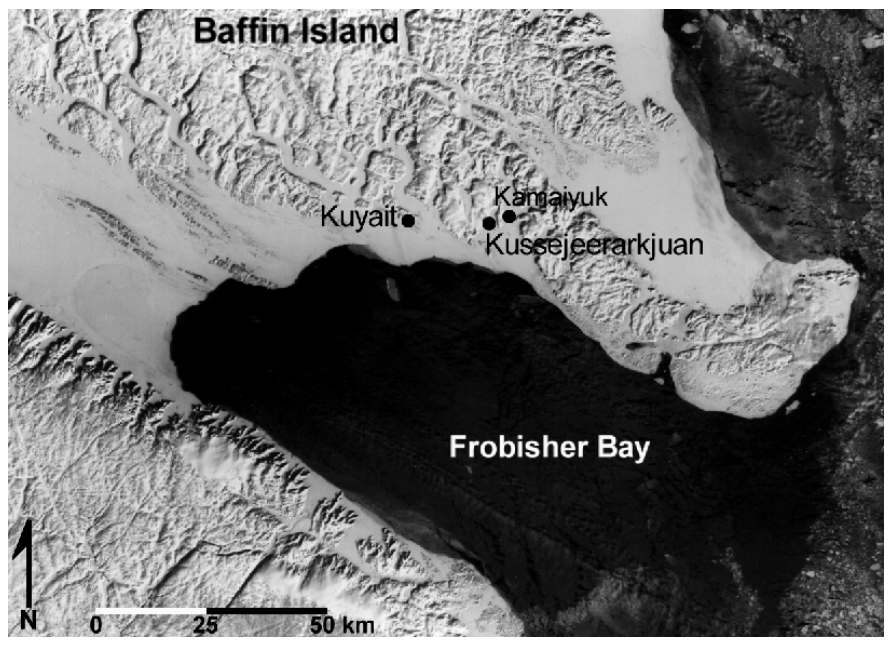

FIG. 1. Landsat 4 image of the outer Frobisher Bay polynya during the sea-ice maximum (26 March 1983).

factors including wind, oceanic upwelling, tidal fluctuations, and currents (Stirling, 1980, 1997; Smith and Rigby, 1981). Several specific types of polynyas have been identified, including shore polynyas, limited on one side by the coastline; flaw polynyas, limited on one side by landfast ice; and recurring polynyas, which recur in the same position every year (Schledermann, 1980; Stirling, 1980). Recurring polynyas are very sensitive to climate change. They fall into two types: "those which are open throughout the winter and those which may be ice covered only during the coldest months in some years but which can be relied upon to have at least some open-water early in spring, usually by late March or early April, when the first migrating marine mammals and birds arrive" (Stirling, 1997:10). According to Smith et al. (1979), the recurring polynya situated southeast of Countess of Warwick Sound in outer Frobisher Bay supports moderate numbers of bearded seals year-round, as well as moderate to low densities of polar bears and ringed seals (Fig. 1). It also provides an important wintering spot for belugas and walrus (Stirling et al., 1981:52-53).

The ability to track the size and shape of such polynyas in relation to changing climate is critical to establishing their viability as predictable, resource-rich areas on which Inuit hunters can depend through time. So far, however, few studies have sought to discover whether polynyas, particularly smaller ones, have persisted through periods of climate change. Schledermann's (1980) pioneering work documenting the association between the location of present-day polynyas and 3000 years of human settlement in the High Arctic represented an important starting point. In particular, the climatic models Schledermann employed to study the relationships between changing coastline configurations and polynya formation represented the first means to capture the sensitivity of these features to environmental change through time.

While Schledermann (1980) identified isostatic processes and sea level changes in the High Arctic as important 
factors in assessing polynya formation in the more distant past, such factors are not considered in the context of the more recent periods discussed here. Eustatic sea level rise reached its present-day level along the southeast coast of Baffin Island by 5000 B.P, and uplift ceased in outer Frobisher Bay by approximately 3000 B.P. Geomorphological studies from the area indicate that the land has submerged relative to the sea by one to two meters over the last 2000 years (Miller et al., 1980). While the impact of such submergence is not the focus of the present study, it is unlikely that this process dramatically altered oceanic upwelling, currents, or tidal fluctuations.

Since Schledermann's publication, advances in paleoclimate research, the growth in GIS applications in archaeology, and more robust zooarchaeological analyses can be used to build on these initial results to better track polynyas diachronically. A recent study that relates seal ratios and life-history data from faunal remains recovered at historic Inuit archaeological sites located in proximity to present-day recurring polynyas in Labrador and Baffin Island begins to move in such directions (Woollett et al., 2000). However, the zooarchaeological record by itself cannot be used as a direct biological indicator of past environments. It is an artifact: a cultural filter that represents not only the remains of human choice, but also preservation and excavation bias. Therefore, zooarchaeology must be used in combination with other lines of evidence to reconstruct polynya formation and persistence through time. A variety of environmental indicators are used here to examine how changing climate may have affected the outer Frobisher Bay polynya and how such changes might have influenced historic Inuit resource procurement choices and settlement strategies through time.

What, if any, impact would changing climatic conditions have on the marine mammal and sea bird populations supported by a polynya similar to the one in outer Frobisher Bay? A study of severe sea-ice conditions, which caused the restriction of open-water and, consequently, of polynya formation in the Beaufort Sea region between 1973 and 1975 , found that the numbers of ringed and bearded seal were reduced by $50 \%$ and reproductive rates by about $90 \%$ (Stirling et al., 1981). The reasons for these reductions are related to several factors, including (1) the heavy compression of ice, which makes it difficult for seals to maintain breathing holes, and (2) the reduction of sunlight, which drastically lowers primary productivity and thus the ability for higher-level organisms to sustain themselves (Stirling et al., 1981). This study provides clear evidence that an increase in ice severity directly affects the biological productivity of polynyas.

The distribution of pack ice and open water in winter is another key variable that affects the availability of marine species. Specifically, open water-adapted species, such as walrus, seek winter habitat in shallow areas of open water or moving pack ice, where they can both haul out to breathe and access feeding grounds (Born et al., 1994, 1995). Although it is unclear whether walrus ever engaged in large-scale migrations following the advance and retreat of seasonal pack ice, the most recent biological studies indicate that they no longer move in large numbers along the Baffin Island coastline. Research on the Atlantic walrus (Odobenus rosmarus rosmarus) indicates that this species currently lives in groups that are more sedentary. For example, walrus found in Hudson Bay, Hudson Strait, and Frobisher Bay may represent one group, which moves into Hudson Strait in the spring and departs in the late fall, wintering along the ice edge of Davis Strait (most likely in the vicinity of Loks Land and the northeast end of Frobisher Bay) (Born et al., 1994). These studies suggest that the endurance of the outer Frobisher Bay polynya during periods of climate cooling would represent critical winter habitat, allowing species such as walrus to stay near south Baffin Island year-round.

\section{PALEOCLIMATIC CONTEXT}

Baffin Island is particularly sensitive to changing climatic conditions because of its location relative to the mean position of the mid-tropospheric trough over northeastern North America (Williams, 1979; Williams and Bradley, 1985). This sensitivity is best documented in the highly variable climatic fluctuations recorded in the area over the past 40 years: unusually warm summer temperatures often follow extremely cold winters, and vice versa (Bradley, 1973).

The last 500 years are characterized by similar high climatic variability. The two major global climates typically characterizing the late Holocene are (1) the Medieval Optimum, a warm period spanning roughly A.D. 12501500; and (2) the Little Ice Age (LIA), a cool period spanning ca. A.D. 1600-1850 (Grove, 1988; Houghten et al., 1992; Overpeck, 1997). In the Arctic, the Medieval Optimum coincided with improved ice conditions. Thule peoples expanded into the eastern Arctic during this period, taking advantage of open-water conditions and the large whale species (Baleana mysticetus) they supported. They began to abandon the High Arctic under the more severe ice conditions characterizing the onset of the Little Ice Age. From the 17th century on, and in some cases earlier, Thule culture can be characterized by a number of regionally specific hunting strategies, but sealing and caribou hunting represented economic mainstays.

Although current research generally supports the climatic periods as suggested, recent studies of high-resolution summer temperature records from different sectors of the globe show that climatic trends for the period, particularly during the LIA, were not synchronous or homogeneous and that both warm and cold periods were in effect (Bradley and Jones, 1993). Because variations in seasonal climate are common in the Arctic, reconstructions that produce annual trends are not particularly useful. Therefore, for reconstructing temperature, only ice core melt studies and tree ring data, which provide information on 
summer trends, are included in this discussion. Recent studies on the Penny Ice Cap, located on Cumberland Peninsula, Baffin Island, provide proxy data for reconstructing spring sea-ice conditions. Specifically, they found an inverse correlation between marine aerosols (namely sea salt) and sea ice in the Labrador Sea/Baffin Bay region. Higher concentrations of sea salt preserved in the ice core indicate conditions with more open water, while lower concentrations indicate more severe ice conditions, which cause marine aerosols to become trapped under the ice (Grumet, 1997; Grumet et al., 2001). Together, temperature and sea-ice reconstructions provide high-resolution data with which I evaluate the environmental context of Nugumiut subsistence practices.

Data from ice core melt studies, dendrochronology, and the sodium record from the Penny Ice Cap for the period A.D. 1500-1990 are plotted in Figure 2. The high temporal resolution of these records makes regional variability evident. However, these data also show strong correlations between lower-than-average temperatures and increased sea-ice severity in the eastern Canadian Arctic. Specifically, the period between ca. A.D. 1500 and 1740 shows increased ice severity and lower-than-normal temperatures except for the mid 16th century. More severe conditions again go into effect ca. A.D. 1800-1875, with a trend towards ameliorating sea-ice conditions through the 20th century. One noted exception relates to the last 30 years, when some temperature data continue to rise while sea-ice conditions deteriorate.

Although anecdotal, C.F. Hall's (1866) observations of environmental features prevalent in outer Frobisher Bay and Cyrus Field Bay in the early 1860s provide a firsthand account of winter sea-ice conditions in this area. One such observation included the persistence of open-water conditions during the winter months. As Hall (1866:305) states: "Here before me, looking southerly, was the open-water of Lupton Channel, which as my native attendants informed me, never freezes over [emphasis Hall's], in consequence of the swiftly-running tides." Lupton Channel is strikingly close to the modern polynya, being situated along the northeastern border of its present location. Hall (1866:259 260) also made references to open water in outer Frobisher Bay in April, suggesting, at the very least, that sea ice broke up early in this portion of the Bay. The Penny Ice Cap data show that this period was particularly severe in terms of ice, suggesting that the polynya persisted despite the harsh conditions (Grumet et. al., 2001). The following GIS analysis of modern sea-ice extremes helps to document the spatial range of ice conditions that could have been in effect during the periods of human habitation represented in outer Frobisher Bay.

\section{METHODS}

All data for the GIS analysis were generated on a Hewlett Packard 730 workstation using the UNIX version of Arc/Info, a vector-based software program designed by the Environmental Systems Research Institute, Inc. (ESRI). The base map for south Baffin Island was created using the Digital Chart of the World (DCW), also a product of ESRI. This chart was produced from the U.S. Defense Mapping Agency Operational Navigation Chart (ONC) series at a scale of 1:1000000.

\section{Archaeological Settlement Pattern Data}

Archaeological site data, provided by the Archaeological Survey of Canada (ASC) and the Prince of Wales Northern Heritage Centre in Yellowknife, Northwest Territories, cover 383 sites located between $61^{\circ}$ and $67^{\circ} \mathrm{N}$ and between $62^{\circ}$ and $74^{\circ} \mathrm{W}$ (Fig. 3). The delineation of this region was chosen for two reasons: (1) the area is large enough to look comparatively at Frobisher Bay and Cumberland Sound, as well as examine coastal-inland site distribution; and (2) extensive archaeological surveys have been conducted in the area. The information included in the ASC database varied according to the recording strategies of individual principal investigators, but certain basic data, such as cultural affiliation and architectural features, were documented for each site.

To ensure consistency, several definitions were made explicit before data entry began. Continuous-occupation Neoeskimo sites were defined by the presence of both Thule and historic Inuit artifacts. If data relating to cultural affiliation were missing, then sites would not be assigned to a specific period. Assignment of cultural affiliation within multi-component sites was based on the presence or absence of specific artifact types. Precolonial Thule designations were based on the presence of harpoon types, lab dates, and the absence of European material culture, i.e., rifle parts, European ceramics, steel fox traps, etc. The historic Inuit designation was based on the presence of European material culture mentioned above.

For this study, "winter" and "spring" designations were based on the presence of semi-subterranean habitations. Although winter might not have been the only season in which such structures would have been occupied, it most likely represents the primary season of occupation. Although summer and spring are also critical for understanding polynya formation and productivity, I chose to examine winter because the ice edge habitat during this season appears to be one of the major reasons why certain more open water-adapted species, such as walrus, remain in particular areas year-round. Winter is also a time when we can gauge the relative contribution of fast ice and floeedge hunting through seasonality studies of ringed seal canines. When possible, I used the information contained in the ASC database in conjunction with available published data pertaining to the sites under investigation. Of the 383 sites entered into the database, 42 were used in the final analysis. Selection criteria were requisite seasonality (winter occupations) and time period (Thule, historic Inuit, Neoeskimo). 
Devon Ice Melt (Koerner 1977; Koerner and Fisher, 1990)

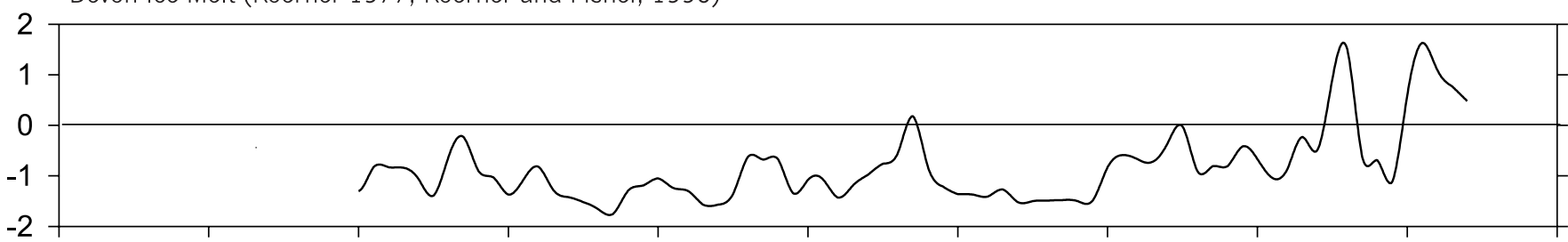

Greenland Ice Melt (Kameda et al., 1992; Bradley and Jones, 1993)

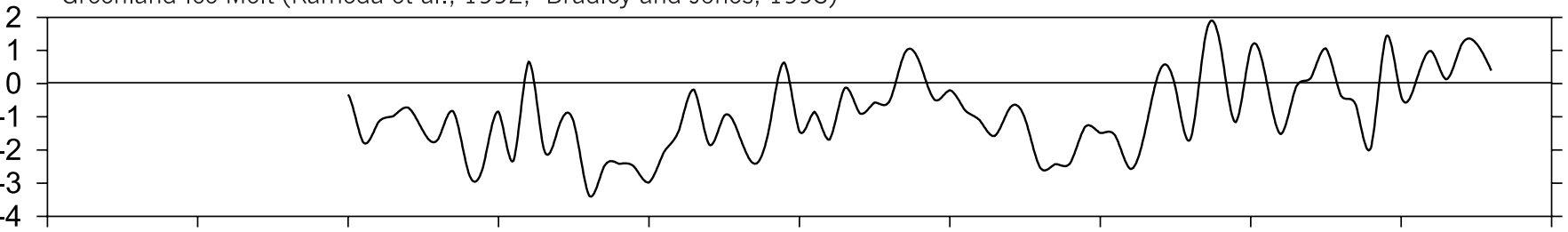

Okak Tree Ring (Jacoby and D'Arrigo, unpublished data)

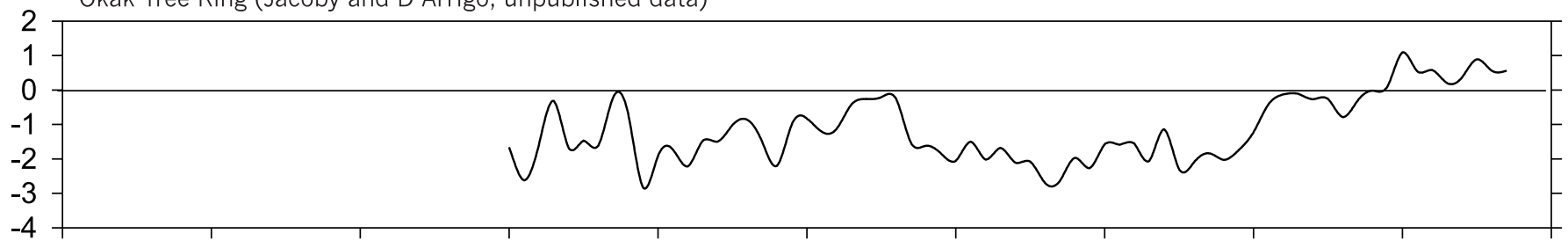

Castle Tree Ring (Jacoby and D'Arrigo, 1989; D'Arrigo and Jacoby, 1992,1993)

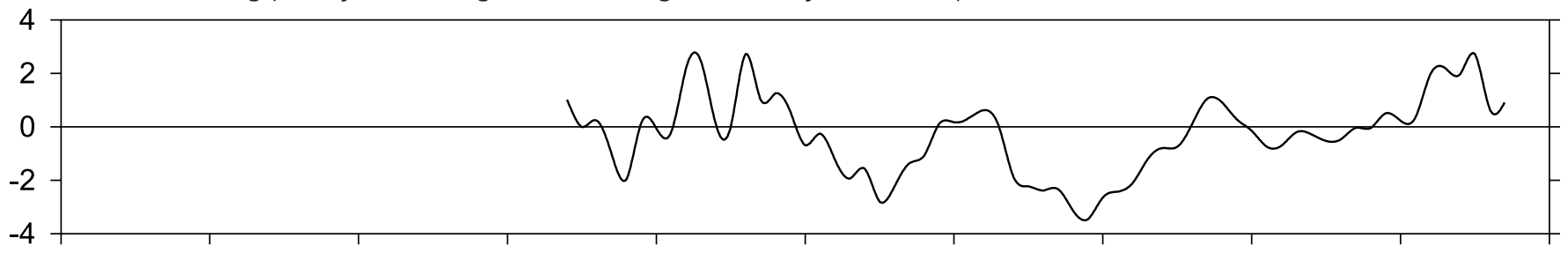

Kuujuaq Tree Ring (Jacoby and D'Arrigo, 1989)

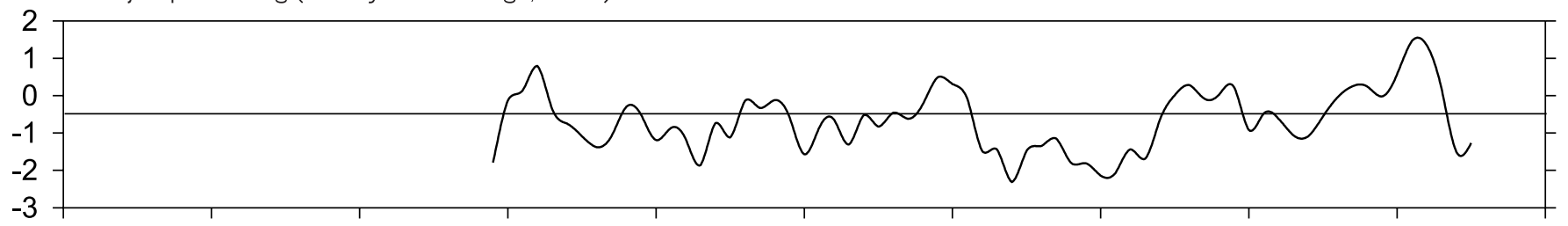

Salt Water Pond Tree Ring (Jacoby and D'Arrigo, unpublished data)

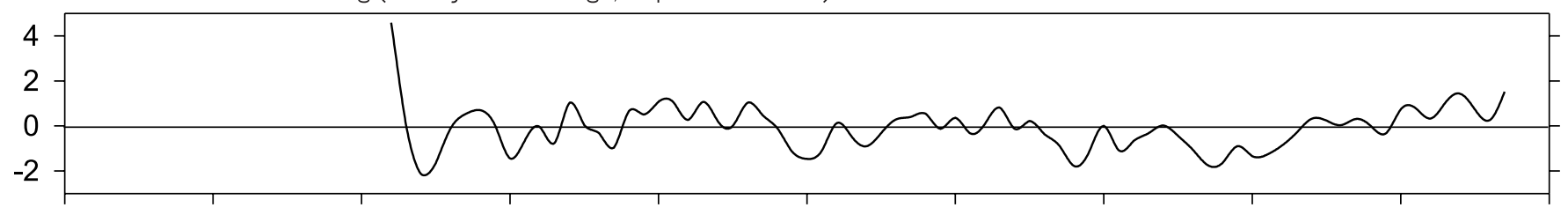

Penny Ice Cap Sodium Record (Grumet et al., 2001)

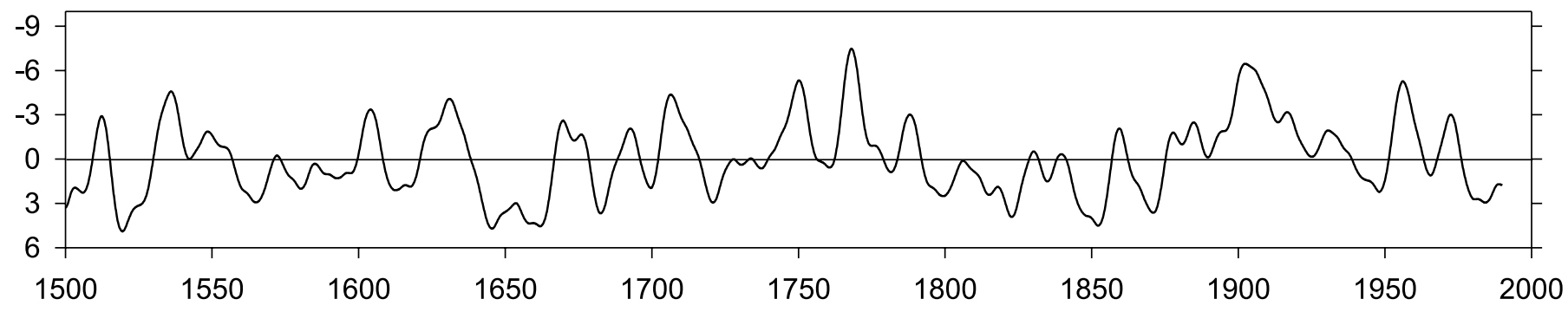

FIG. 2. Temperature data (from studies of ice core melt and dendrochronology) in relation to sea-ice formation (from the sodium record from the Penny Ice Cap, A.D. 1500-1990). All temperature reconstructions (graphs 1-6) are based on data compiled by Overpeck (1997) for A.D. 1600-2000. The vertical axes represent standard deviations, either positive (warmer) or negative (cooler), from the average temperatures recorded during the reference period 1901-1960. The sea-ice reconstruction (graph 7) is based on data presented by Grumet et al. (2000). 


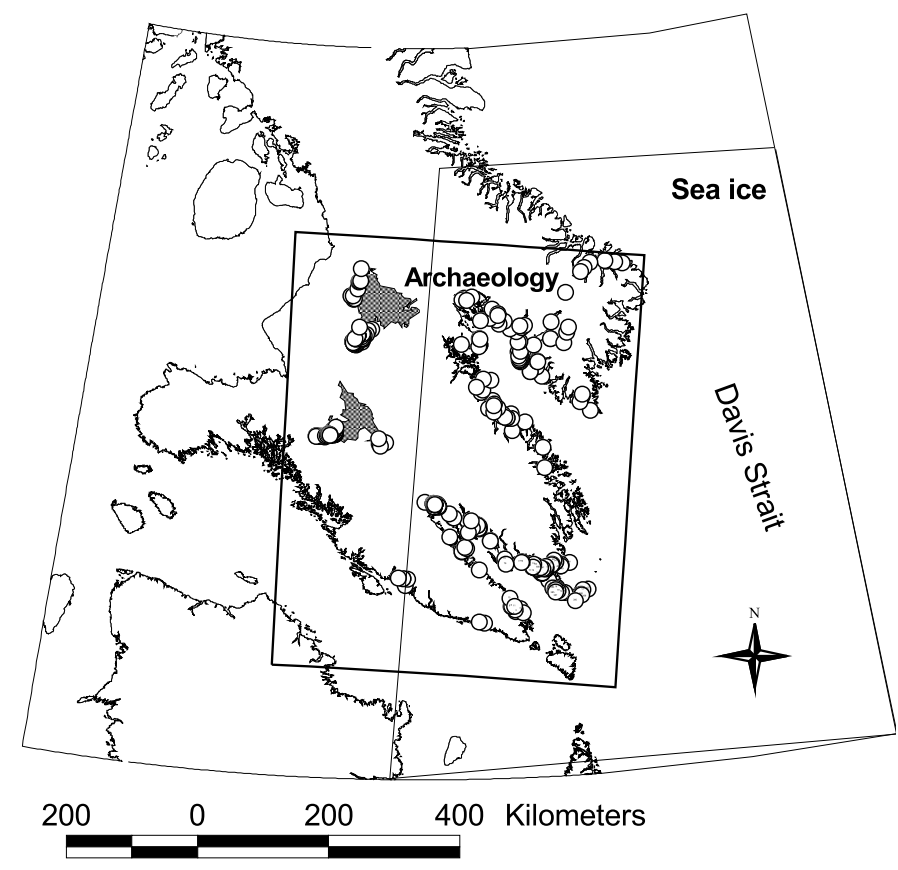

FIG. 3. Area of coverage for the archaeological sites included in the GIS settlement pattern analysis and the GIS sea-ice analysis.

\section{Archaeological Excavations in Outer Frobisher Bay}

The faunal results described in this study are based on assemblages recovered by the author while a member of the Meta Incognita Project. They come from three historic Inuit habitation sites in outer Frobisher Bay, Baffin Island: Kamaiyuk, Kuyait, and Kussegeerarkjuan (Fig. 1) (Alsford, 1993; Henshaw, 2000). Thirteen habitations were excavated over the course of two summer field seasons. Two general periods of historic Inuit habitation were identified: (1) protohistoric Inuit (ca. A.D. 1350-1850), characterized by intermittent contact between Inuit and early European explorers, and (2) late historic Inuit (ca. A.D. 1850-1930), which consisted of prolonged interaction of Inuit with fur trappers/traders, Royal Canadian Mounted Police (RCMP), and missionaries who worked in the region (Henshaw, 1999). The long time span represented by the protohistoric period is a broad estimate based on calibrated $\mathrm{C} 14$ date ranges associated with the site of Kamaiyuk. Recent analyses of diagnostic artifact types for this site show the most concentrated period of occupation between A.D. 1500 and 1800 (Gullason, 1999). From a climatic standpoint, ice core melt studies clearly suggest intermittent cooler conditions during the period when Kamaiyuk was occupied. For the mid-20th century, ice melt data, together with sea-ice reconstructions from the Penny Ice Cap, show below-average but ameliorating conditions between A.D. 1910 and 1930, the period corresponding with most of the late historic occupations of Kussejeerarkjuan and Kuyait.

Of the 20399 bones recovered from the three sites, 6351 (31\% of the total assemblage) were identified to genus or species level. Kuyait yielded the greatest number of bones
(8857), followed by Kamaiyuk (8627), and Kussejeerarkjuan (2915). Bones recovered from old sod wall and recent sod matrices were not included in this analysis (exceptions were those found in qarmat structures, where bones associated with the occupation of the house were located just below the sod). However, "wall fall" deposits (faunal remains found in loose fill, where walls had collapsed into house interiors) were used in the analysis because these remains most likely represented the clearing of house interiors during occupation. The unit of analysis employed in this study is the household, and faunal remains were quantified using three standard measures: NISP (Number of Identified Specimens), MNI (Minimum Number of Individuals), and RF (Relative Frequency).

Kamaiyuk: Kamaiyuk is located approximately $3 \mathrm{~km}$ northeast of Kodlunarn Island, at the southern tip of a small rocky peninsula on the west side of Napoleon Bay in Countess of Warwick Sound (Fig. 1). On the site are 12 visible cultural features, which overlay rich Paleoeskimo midden deposits. The main features include three large, bilobate semi-subterranean structures, one single-lobe semi-subterranean structure, two half-eroded semi-subterranean structures on the northeast bank of the site, five heavily constructed tent rings, and one cobble stone cache. Kamaiyuk represents the largest protohistoric Inuit site in Countess of Warwick Sound. As mentioned above, the most concentrated period of occupation dates between ca. A.D. 1500 and 1800 (Henshaw, 2000: Table 2; Gullason 1999: Fig. 14). Although faunal preservation at the site was generally good, soil $\mathrm{pH}$ at the site was fairly acidic (4.1 to 5.0). In addition, erosional forces from the sea, in combination with land submergence, had destroyed entrance passages, as well as some house fronts and exterior midden deposits.

Kuyait: Kuyait is located on a sage meadow enclave at the southwestern entrance of Wiswell Inlet, approximately $12 \mathrm{~km}$ northwest of Countess of Warwick Sound (Fig. 1). The site consists of 18 visible cultural features on the ground surface, which overlay rich Paleoeskimo midden deposits. The features include nine semi-subterranean dwellings with heavy stone and sod wall construction, three qarmat similar to Stenton's (1989:156) type d/e, two tent rings, three caches, and a wooden box burial (not disturbed during our excavations). At higher elevations $(100 \mathrm{~m})$ northwest of the site, three other caches were identified, in addition to a stone fox trap, all of which had extensive lichen cover. During 1991 and 1992, we excavated five structures (Houses 3, 5, 8, 11, 12) each representing different seasonal and temporal phases of historic Inuit occupation. A combination of land submergence, coastal erosion, and solifluction had caused the deterioration of certain houses (especially House 3 and House 8) and their associated midden deposits. House 3 represented the only precontact structure, but because of solifluction processes and a poor sample size, faunal remains from this structure were not included in the present analysis. House 5 included three occupations: (1) a protohistoric Inuit 
occupation dating between A.D. 1440 and 1660, (2) an early historic occupation dating between A.D. 1770 and 1850, and (3) a later historic occupation dating approximately to the 1920s. Since the stratigraphic separation between occupations one and two was poor and sample size was small, only occupation three was included in this study. Houses 11 and 12, both qarmat, date to the 1920s and were most likely contemporaneous with the late historic occupation of House 5 (i.e., 1920s). House 8, a large bilobate semi-subterranean structure, dates approximately between A.D. 1850 and 1900. Bone preservation was highly variable at the site, with soil $\mathrm{pH}$ reading between 4.4 and 5.3. Faunal remains from late historic qarmat structures were in stable condition, but acidic soil had produced heavily pitted bone cortexes. The earlier historic Inuit deposits were in fair to poor condition.

Kussejeerarkjuan: This site is located on the west side of the entrance to Diana Bay, $2 \mathrm{~km}$ northwest of Kodlunarn Island in Countess of Warwick Sound (Fig. 1). The site lies in an open sage meadow facing west, with a large lake system and two large caribou drives located several hundred meters up a steep embankment to its north. Kussejeerarkjuan consists of at least 26 cultural features all visible on the ground surface: 11 qarmat, 10 standard stone line tent rings similar to Stenton's (1989:156) type b, 4 caches, and 1 box hearth feature. No Paleoeskimo artifactual remains were recovered from this site, making it one of the few single-component late historic Inuit sites in the area. During the 1992 field season, we excavated three of the habitation structures, two qarmat (Houses 2 and 3) dating from ca. A.D. 1920-1930, and one tent ring (House 6) occupied between ca. A.D. 1910 and 1918 (Gullason, 1999: Table 33). Exterior midden deposits were tested, but little bone was recovered. Faunal preservation was good, although the total number of bones was smaller than in the large semi-subterranean structures at Kuyait and Kamaiyuk, probably because these less permanent structures had a shorter occupation.

\section{Sea Ice}

I used two sources of data to investigate interannual variation in sea ice. Maximum and minimum sea-ice extents for summer and winter in the Davis Strait/Labrador Sea area are based on an ongoing study by Chapman and Walsh (1993: Fig. 7b) that has tracked sea-ice concentration in the region since 1953. For the present study, ice anomalies for the North Atlantic sector (defined by a two standard deviation departure from normalized sea-ice concentration monthly means) were chosen for winter/spring (December-May). The anomalies include a winter sea-ice maximum (March 1983) and winter sea-ice minimum (February 1981).

Weekly sea-ice compilation charts for these months were obtained from the Atmospheric Environment Service, Environment Canada, Ice Climatology and User Application Division, Ottawa. The sea-ice information recorded on these charts consists of polygons, each of which contains specific attribute data pertaining to several key sea-ice characteristics present within them. These include (1) total tenths of ice concentration; (2) the partial concentration of various ice types, including the forms of ice (floe sizes); and (3) the various developmental stages of ice present. Using the sea-ice compilation charts as a base map, I digitized sea-ice polygons correlating with the sea-ice minimums and maximums defined earlier for the area within $56^{\circ}-70^{\circ} \mathrm{W}$ and $60^{\circ}-69^{\circ} \mathrm{N}$ (Fig. 3). These data were then converted into polygon coverages in Arc/Info and joined with an attribute table based on sea-ice data gathered and defined by Environment Canada. For the purposes of this study, I considered total tenths of ice concentration to be the attribute most relevant for tracking polynya formation through time.

\section{RESULTS}

\section{Modern Sea-ice Variability in Relation to Historic Inuit and Thule Site Distribution}

Figure 4 shows the spatial distribution of sea-ice concentration for the modern winter sea-ice minimum and maximum in relation to Thule and historic Inuit winter habitation sites. Using the criteria described earlier, I identified a total of 14 prehistoric Thule sites, 14 historic Inuit sites, and 14 continuous Neoeskimo habitation sites. For Frobisher Bay, these data show a modest increase in the number of historic Inuit winter habitations in the outer Frobisher Bay region compared to Thule times. In Cumberland Sound, the settlement distribution shows a clear continuity between the two periods, with settlement concentrating near the head of the Sound. This pattern, however, could be an artifact of the surveys, which have focused primarily on the inner Sound region (Schledermann, 1975).

Open-water leads occur at the intersection of two polygons. During the winter minimum, the outer limit of land fast ice lies close to the coastline, especially in upper Frobisher Bay (Fig. 4a). During the winter maximum, however, landfast ice extends significantly toward the outer Bay region, although the floe edge near archaeological sites in the Countess of Warwick Sound remains fairly constant (Fig. 4b). The presence of this particular floe edge demonstrates the persistence of the northeastern end of the polynya, even during severe ice years. Figure 1 shows a view of the outer Frobisher Bay polynya at the winter maximum, from a Landsat image taken on 26 March 1983. This image shows the size and shape of the polynya, as well as its proximity to the archaeological sites examined in this study.

The results of this analysis have important implications for the nature of settlement distribution in Frobisher Bay during the LIA and earlier. Groups located at the head of Frobisher Bay would have been the most vulnerable to 
(a)

$\bigcirc$ Thule

$\triangle$ Historic Inuit

$\square$ Continuous Habitation

Tenths of Ice Concentration

$\approx 8$

10

$9+$

$<1$
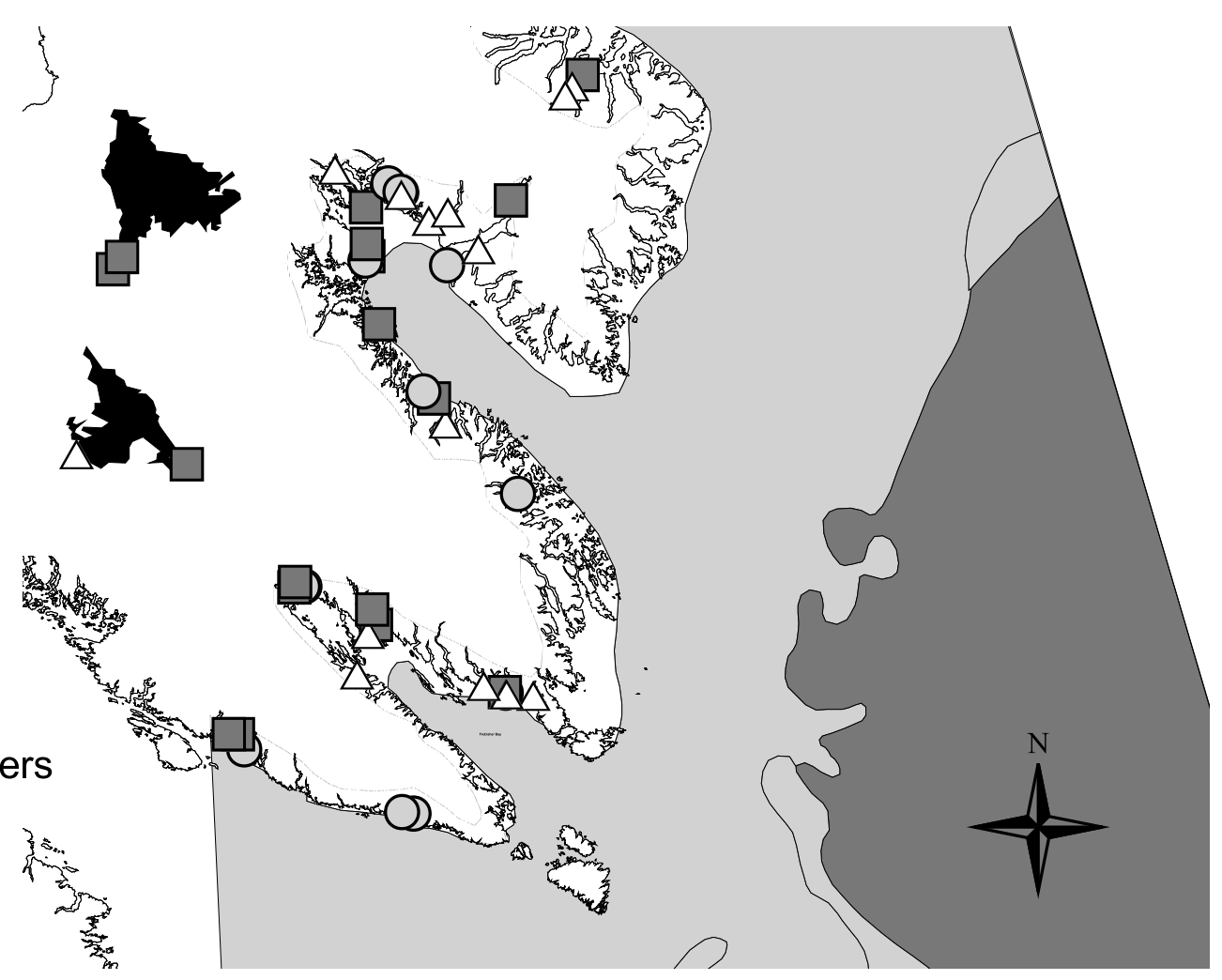

(b)

$\bigcirc$ Thule

$\triangle$ Historic Inuit

Continuous Habitation

Tenths of Ice Concentration

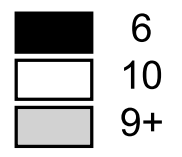

100 Kilometers
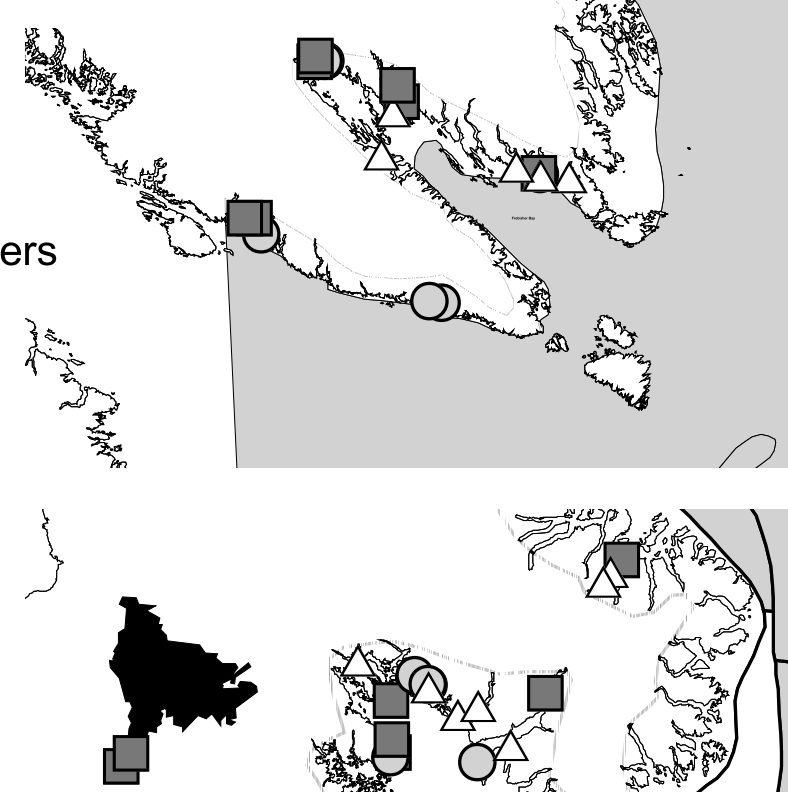


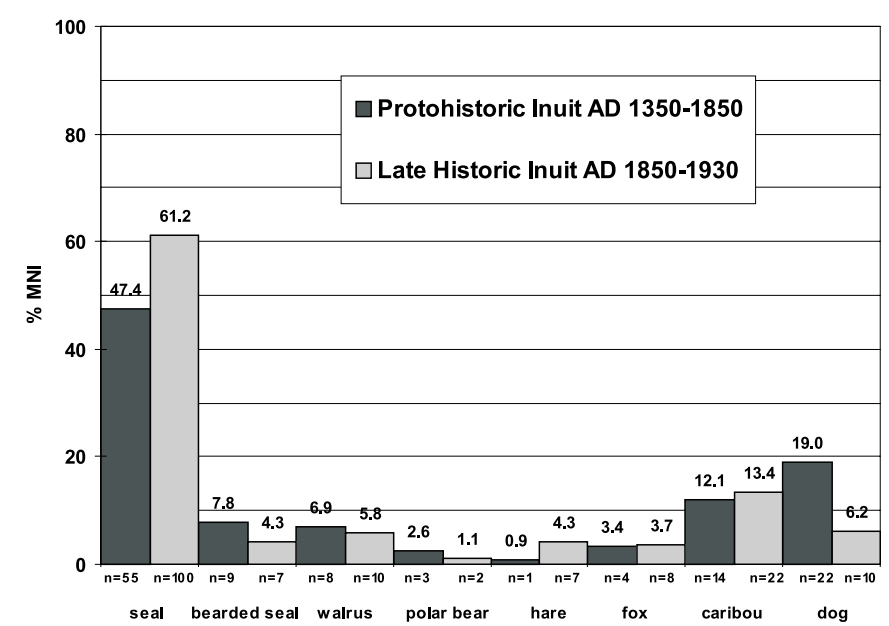

FIG. 5. Non-cetacean mammals (\%MNI) recovered from Kamaiyuk, Kuyait, and Kussejeerarkjuan.

dominates the collection. Zooarchaeological analyses from Peale Point also show that land mammals, especially caribou, remained important throughout the various phases of occupation. Open-water species, such as walrus and bearded seal, were consistently underrepresented in the faunal remains. During Neoeskimo and Inuit occupations (A.D. 1000-1940) represented at the Tungasivvik site, located near Peale Point at the head of Frobisher Bay, ringed seal accounted for $60 \%$ of the faunal remains, caribou 25\%, and all other species less than 5\% (Stenton and Rigby, 1995:53). These percentages are similar to those found in the outer Bay region for both the early and late historic Inuit periods. They may indicate that the ice edge was closer to the head of Frobisher Bay between A.D. 1000 and A.D. 1650 (Stenton and Rigby, 1995:51), a time period representing the most concentrated occupation at the site and a time of ameliorating climatic conditions characterizing the Medieval Climatic Optimum. However, since Stenton and Rigby's (1995) analysis does not break up species frequencies by season, the relative importance of floe-edge versus landfast-ice hunting at Tungasivvik is difficult to evaluate.

Jacobs and Stenton (1985:73) interpret the abandonment of permanent winter camps in the area by A.D. 1850 as the cumulative result of "reduced terrestrial productivity and an expanding fast ice environment." They suggest that these factors may have led people to move towards the mouth of Frobisher Bay to take advantage of the floe edge. The outer Frobisher Bay polynya, which persisted despite episodes of cooling, most likely represented a predictable, resource-rich habitat not only for hunters already living in the outer Bay region before A.D. 1850, but also for the later influx of Inuit migrants drawn to this area from the head of Frobisher Bay. The presence of Hudson's Bay Company posts in the mid and outer Bay area from 1914 onwards may also have contributed to later movements of people to this area (Henshaw, 2000).

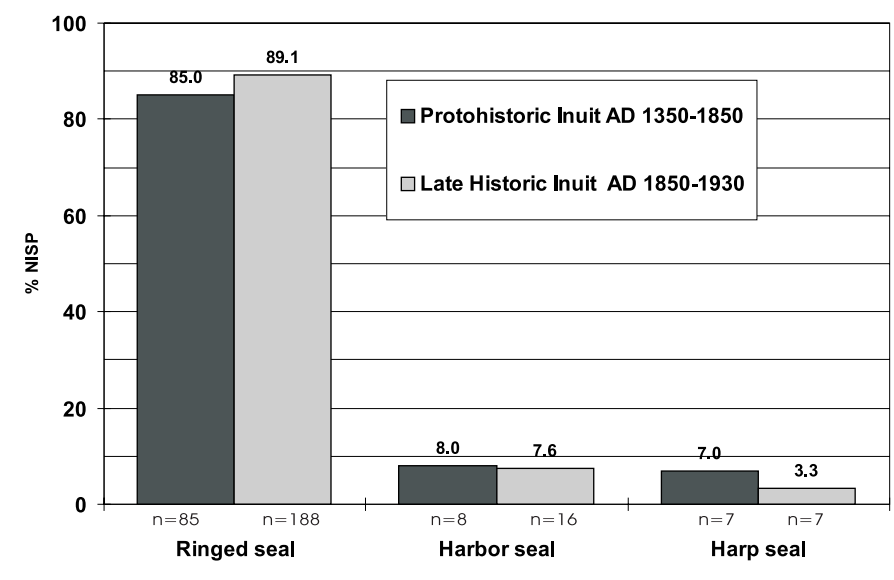

FIG. 6. Phocids (\%NISP) recovered from Kamaiyuk, Kuyait, and Kussejeerarkjuan.

\section{Zooarchaeological Analyses in Outer Frobisher Bay}

Figure 5 shows the relative percentages of non-cetacean mammalian species representing the protohistoric Inuit and late historic Inuit periods at Kamaiyuk, Kuyait, and Kussejeerarkjuan. Small phocids are the most abundant taxon identified, accounting for $47.4 \%$ to $61.2 \%$ of the total. The total NISP counted within the small phocids indicate that ringed seals occur most frequently ( $85 \%$ to $89.1 \%$ of this group; Fig. 6). Based on the high percentage frequencies of ringed seals, it is likely that the extensive landfast ice habitat characterizing this region probably played an important role in determining, in part, the availability of this species during both the early and late historic periods.

The incremental structures preserved in the cementum and dentine of ringed seals' canine teeth provide additional evidence for use of the outer Bay polynya. Modern studies of ringed seal populations along south Baffin Island have shown that dense, opaque dentine is laid down between July and March, while translucent dentine is deposited from the end of March to the end of June (MacLaren, 1958; Smith, 1973; Stewart et al., 1996). Reticulated (vacuolated) dentine is not deposited as regularly. Sometimes it appears to overlie (or be formed during the deposition of) the opaque band; at other times, it appears at the border of the opaque band (Smith, 1973). Results of thin section analyses show that the remains of both immature and mature ringed seals are present at all three sites (Fig. 7 and Table 1).

At Kamaiyuk, juvenile seals (1-6 years old) came exclusively from House 3 , while the mature ringed seals ( $7+$ years old) were spread among Houses 2, 3, and 4. Of those that could be read for season of procurement, both a winter and a summer kill were identified (Table 1). The summer kill was of a mature seven-year-old ringed seal. The ringed seal canine identified as a winter kill, recovered from House 3, came from a juvenile animal. 
TABLE 1. Seasonality designations assigned to ringed seal canines recovered from historic Inuit archaeological sites in outer Frobisher Bay.

\begin{tabular}{|c|c|c|c|c|c|c|c|c|c|c|c|c|c|c|}
\hline \multirow[t]{2}{*}{ Site } & \multirow[t]{2}{*}{ House } & \multirow[t]{2}{*}{ Catalogue \# } & \multicolumn{5}{|c|}{ Winter } & \multicolumn{2}{|c|}{ Spring } & Summer & \multicolumn{3}{|c|}{ Fall } & \multirow[t]{2}{*}{ Age } \\
\hline & & & $\mathrm{D}$ & $\mathrm{J}$ & $\mathrm{F}$ & M & A & M & $\mathrm{J}$ & A & S & $\mathrm{O}$ & $\mathrm{N}$ & \\
\hline \multirow[t]{5}{*}{ Kussejeerarkjuan } & 3 & $1101-5$ & & & & & & & & & & & & 5 \\
\hline & & $1112-15$ & & & & & & & & & & & & 3 \\
\hline & & $1125-17$ & & & & & & & & & & & & 3 \\
\hline & & $1129-127$ & & & & & & & & & & & & 5 \\
\hline & 6 & $1081-121$ & & & & & & & & & & & & 0 \\
\hline \multirow[t]{2}{*}{ Kamaiyuk } & 2 & $160-59$ & & & & & & & & & & & & 7 \\
\hline & 3 & $906-105$ & & & & & & & & & & & & 5 \\
\hline \multirow[t]{3}{*}{ Kuyait } & 5 & $812-91$ & & & & & & & & & & & & 1 \\
\hline & (Late Hist) & $711-83$ & & & & & & & & & & & & 1 \\
\hline & & $711-87$ & & & & & & & & & & & & 1 \\
\hline
\end{tabular}

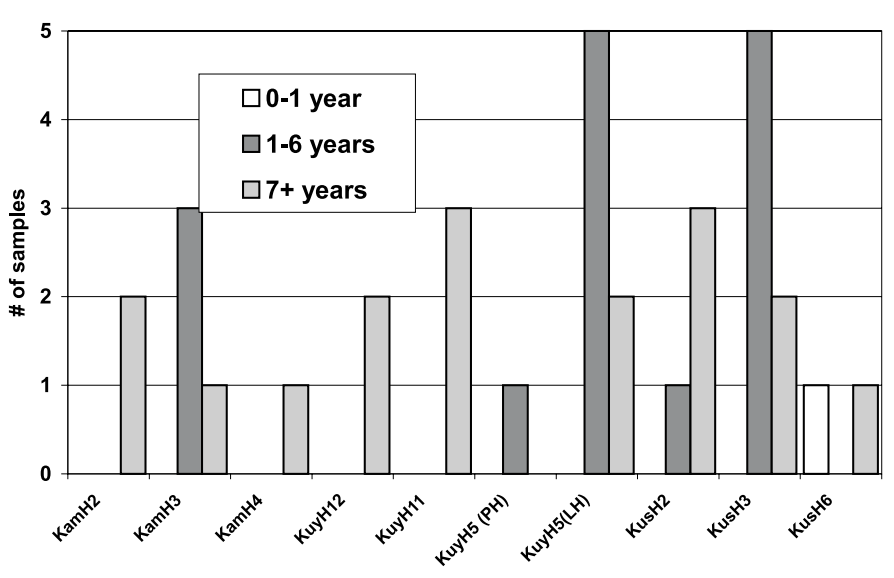

FIG. 7. Age structure of ringed seals recovered from Kamaiyuk, Kuyait, and Kussejeerarkjuan, as determined by thin-section analysis of canine teeth.

At Kuyait, mature ringed seals were the dominant age class; their remains were recovered mainly from House 11 and House 12 (Fig. 7). At House 5, in contrast, five of the seven canines recovered from the late historic levels came from juvenile animals, while just two came from mature animals. The specimens that could be read for seasonalitya one-year-old ringed seal harvested between January and March, a one-year-old harvested sometime between September and April, and a one-year-old seal harvested between July and August-all came from the historic levels of House 5 (Table 1).

The houses at Kussejeerarkjuan yielded the most robust sample of ringed seal canines for thin-sectioning analysis. Of the seven specimens analyzed from House 3, five were juvenile and two were mature (Fig. 7). House 2 also contained the remains of both juvenile and mature animals. In House 6, the canines of one yearling and one mature ringed seal were identified. Of the juvenile seals recovered from House 3, two were procured during the summer months, while two were winter/spring kills (Table 1). The season of death for the mature seal specimens could not be determined. The yearling identified from House 6 was captured at some time between May and August.

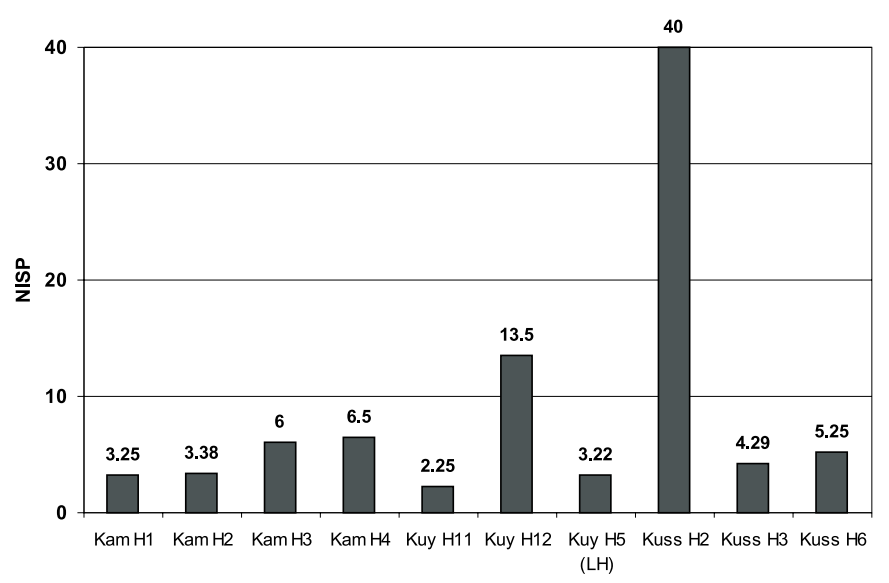

FIG. 8. Ratios of ringed seals to open-water species (bearded seal and walrus) in remains found at the sites under investigation.

The seasonality information revealed through these data suggest that Nugumiut hunters were practicing a mixed strategy, harvesting resources from both the floeedge and landfast-ice habitats, but with more emphasis on the former. Modern population studies of ringed seals show that different age classes segregate between these habitats: juveniles concentrate primarily along the floe edge, while mature and yearling seals congregate in the landfast ice (Smith, 1973). The tooth section analyses from all three sites revealed that juveniles were captured during winter, thus lending support to the notion that the floe-edge habitat, most likely associated with the polynya, was an important environmental feature on which Nugumiut could depend for resources. The use of the landfast-ice habitat is harder to evaluate because season of death is difficult to infer from mature ringed seal canines. The one mature seal that could be read for seasonality (from House 2 at Kamaiyuk) was a summer kill.

The ratio of ringed seals to open-water species (walrus and bearded seal) procured provides additional information on the importance of ice-edge habitats to Nugumiut hunters. NISP ratios calculated by house for the protohistoric period represented at Kamaiyuk are close, $3.25-6.5$ to 1. During the late historic period (for houses 

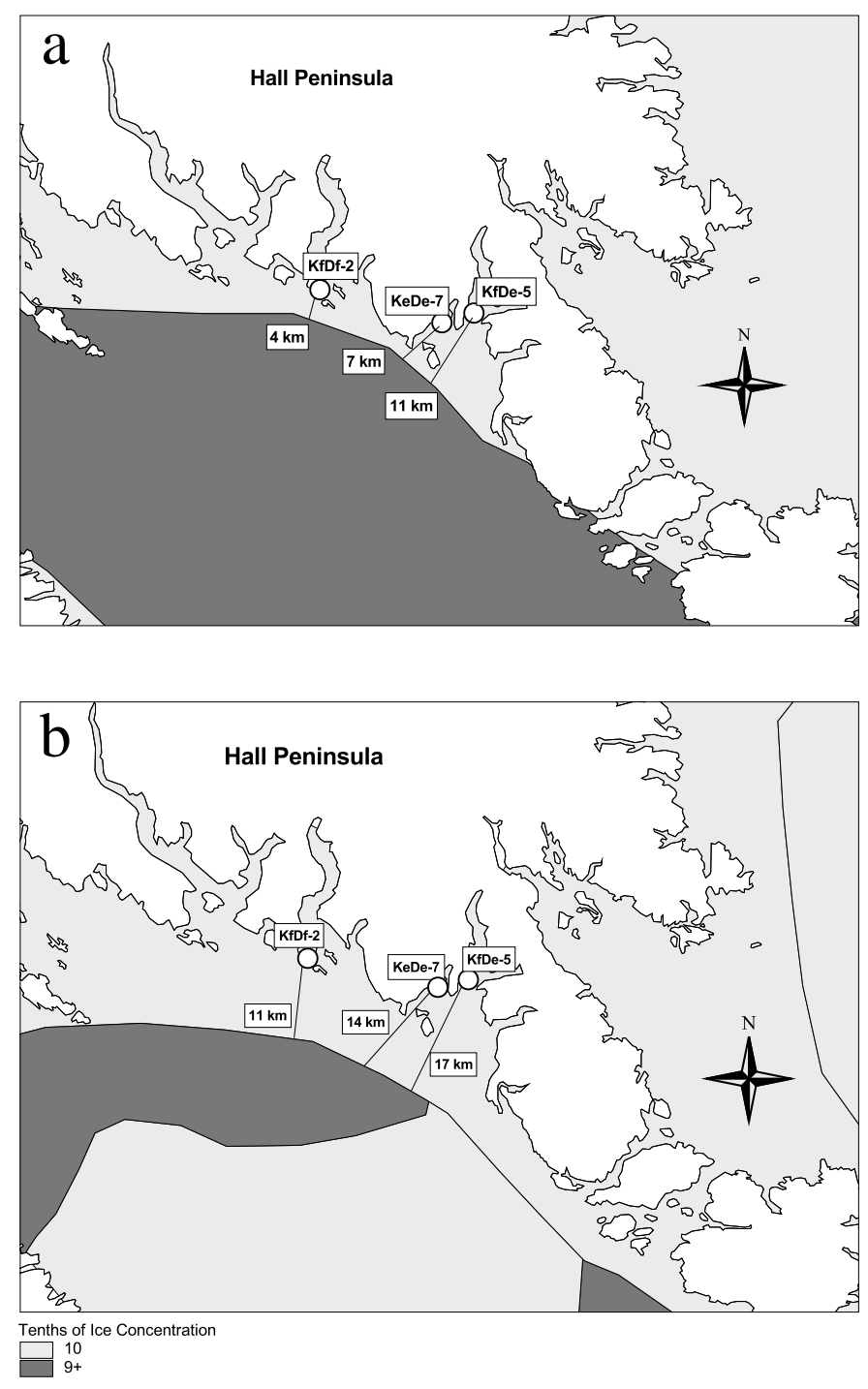

FIG. 9. GIS analysis showing distance from outer Frobisher Bay sites to the ice edge (a) at sea-ice minimum and (b) at sea-ice maximum.

dating between 1910 and 1930), there is also a high degree of consistency, with the exception of House 12 at Kuyait (13.5 to 1) and House 2 at Kussejeerarkjuan, where the ratio of 40 to 1 suggests an overwhelming preference for ringed seals over bearded seal or walrus (Fig. 8). To explain these outliers, it is helpful to revisit the GIS sea-ice maximum and minimum for this region, but at a smaller scale (Fig. 9). Examining the sea-ice extent at this high resolution reveals that the distance to the ice edge from Kuyait and Kussejeerarkjuan decreases by half during the sea-ice winter minimum. These sites are therefore more sensitive to changing ice conditions than Kamaiyuk, where distance to the floe edge, although greater, remained more consistent. The overwhelming number of ringed seals represented in House 12 (Kuyait) and House 2 (Kussejeerarkjun) could indicate particularly severe ice years, when Inuit hunters had to adapt quickly to expanding landfast ice.

\section{DISCUSSION AND CONCLUSIONS}

Placing subsistence within a climatic context is critical for achieving a holistic understanding of Nugumiut cultural history. By making use of the high-resolution paleoclimate data now available, this study has attempted to reconstruct the relationships between climate, polynya formation, and Nugumiut procurement practices and settlement strategies through time. Such reconstructions have shown that the resource-rich polynya, an invariant part of the environmental seascape in outer Frobisher Bay, provided Nugumiut with a sense of predictability in an everchanging and variable climate. The data suggest that the polynya may have been the initial attraction of Thule people to the site of Kamiyuk. The nearby sites of Kuyait and Kussejeerarkjuan represented important Inuit habitations during the late historic period, when the polynya offered economic autonomy for Inuit during a time of intense Inuit-European interaction (Goldring, 1986; Henshaw, 1999, 2000). Interestingly, this pattern continues even today, as many of the outpost residents who have cabins in outer Frobisher Bay use this resource-rich territory to hunt marine and terrestrial resources, maintaining a lifestyle that promotes their own social and economic independence.

The results of the GIS analysis also provided an important modeling tool for visualizing how the outer Frobisher Bay polynya has responded to temperature extremes during the modern period and, by analogy, could have responded to similar conditions in the past. Of particular importance in this analysis was the fact that even during periods of extreme sea-ice severity, the polynya localized in outer Frobisher Bay but remained open. The suggested shift of settlement from the inner to the outer Bay during the late historic period lends support to this conclusion; inner Bay residents followed the expanding ice-edge habitat as their terrestrial adaptation became less dependable. Results of seasonality studies of ringed seal canines, in addition to pinniped ratios, show the importance of the floe-edge habitat to Nugumiut residents in outer Frobisher Bay.

Further research involving interviews with contemporary Inuit hunters about the importance of the polynya to their subsistence-based livelihood, as well as expanded GIS studies, are planned for the future. Contemporary land-use studies and indigenous knowledge projects, like the recent study that took place in the Hudson Bay Bioregion, would improve our understanding of how polynyas may respond to climate change in the future (Freeman, 1976; McDonald et al., 1997). Contemporary Inuit themselves hold the key to understanding what specific conditions affect the viability of polynya formation through time and the ways in which northern communities may choose to adapt to changing ice conditions in the coming decades and centuries. 


\section{ACKNOWLEDGEMENTS}

I thank the community of Iqaluit and the outpost camp residents living in Frobisher Bay, especially the Pishutkie and the Nowdluk families, for allowing me to conduct research in their backyard. I also thank my fellow colleagues on the Meta Incognita Project, the Canadian Museum of Civilization, the Prince of Wales Northern Heritage Centre, and the Museum of Comparative Zoology at Harvard University. Other agencies that provided me important access to environmental and archaeological data included the Ice Climatology and User Division of Environment Canada, the Archaeological Survey of Canada, and the Environmental System Research Institute Inc. Ringed seal canine samples were prepared in the Archaeometry Laboratory at Harvard University and interpreted by Mike Hammill and Jean-François Gosselin of the Department of Fisheries and Oceans, Institut Maurice-Lamontagne, Mont Joli, Quebec.

Financial support came from the Student Fellowship Grant Program at the Canadian Embassy, the National Science Foundation Division of Polar Programs, the Wenner Gren Foundation, Harvard University Summer Field Funds and the National Institute for Global Environmental Change Fellowship Program at Indiana University. I appreciate the comments by several anonymous reviewers, who provided valuable feedback on drafts of this manuscript.

\section{REFERENCES}

ALSFORD, S., ed. 1993. The Meta Incognita Project: Contributions to field studies. Mercury Series Directorate Paper Number 6. Hull, Quebec: Canadian Museum of Civilization.

BARRY, R.G., ARUNDALE, W., ANDREWS, J.T., BRADLEY, R., and NICHOLS, H. 1977. Environmental change and cultural change in the eastern Canadian Arctic during the last 5000 years. Arctic and Alpine Research 9(2):193-210.

BOAS, F. 1964. The Central Eskimo. Lincoln: University of Nebraska Press. (Originally published as part of the Sixth Annual Report of the Bureau of Ethnology, Smithsonian Institution, Washington, D.C., 1888.)

BORN, E.W., HEIDE-JØRGENSEN, M.P., and DAVIS, R.A. 1994. The Atlantic walrus (Odobenus rosmarus rosmarus) in West Greenland. Meddelelser om Grønland, Bioscience 40.

BORN, E.W., GJERTZ, I., and REEVES, R. 1995. Population assessment of Atlantic walruses. Meddelelser Nr. 138. Oslo: Norsk Polarinstitutt.

BRADLEY, R.S. 1973. Seasonal climatic fluctuations on Baffin Island during the period of instrumental records. Arctic 26(3):230-243.

BRADLEY, R.S., and JONES, P.D. 1993. 'Little Ice Age' summer temperature variations: Their nature and relevance to recent global warming trends. The Holocene 3:367-376.

CHAPMAN, W.L., and WALSH, J.E. 1993. Recent variations of sea ice and air temperature in high latitudes. Bulletin of the American Meteorological Society 74(1):33-47.

D'ARRIGO, R.D., and JACOBY, G.C., Jr. 1992. Dendroclimatic evidence from northern North America. In: Bradley, R.S., and
Jones, P.D., eds. Climate since A.D. 1500. London: Routledge. 296-311.

. 1993. Secular trends in high northern latitude temperature reconstructions based on tree rings. Climatic Change 25: $163-177$.

DEKIN, A.A., Jr. 1972. Climate change and cultural change: A correlative study from eastern Arctic prehistory. Polar Notes 12:11-31.

FITZHUGH, W.W. 1972. Environmental archaeology and cultural systems in Hamilton Inlet, Labrador. Washington D.C.: Smithsonian Institution Press.

FITZHUGH, W., and LAMB, H.F. 1985. Vegetation history and culture change in Labrador prehistory. Arctic and Alpine Research 17(4):357-370.

FREEMAN, M.M.R., ed. 1976. Inuit land use and occupancy project. Volumes 1-3. Ottawa: Supply and Services Canada.

GOLDRING, P. 1986. Inuit economic responses to Euro-American contacts: Southeast Baffin Island, 1824-1940. Canadian Historical Association, Historical Papers. 146-172.

GROVE, J.M. 1988. The Little Ice Age. New York: Methuen.

GRUMET, N.S. 1997. Glaciochemical investigations of the last 1,000 years from the Penny Ice Cap, Baffin Island. Master of Science Thesis, Department of Earth Science, University of New Hampshire, Durham, New Hampshire.

GRUMET, N.S., WAKE, C., MAYEWSKI, P.A., ZIELINSKI, G., WHITLOW, S.I., KOERNER, R.M., FISHER, D.A., and WOOLLETT, J. 2001. Variability of sea-ice extent in the Baffin Bay over the last millennium. Climate Change 49:129-145.

GULLASON, L. 1999. Engendering interaction: Inuit-European contact in Frobisher Bay, Baffin Island. Ph.D. Dissertation, Department of Anthropology, McGill University.

HALL, C.F. 1866. Arctic researches, and life among the Eskimaux: Being the narrative of an expedition in search of Sir John Franklin, in the years 1860, 1861, and 1862. New York: Harper \& Brothers.

HENSHAW, A. 1999. Location and appropriation in the Arctic: An integrative zooarchaeological approach to historic Inuit household economies. Journal of Anthropological Archaeology 18:79-118.

- 2000. Central Inuit household economies: Zooarchaeological, environmental, and historical evidence from outer Frobisher Bay, Baffin Island, Canada. British Archaeological Reports, International Series 871. Oxford: Archaeopress.

HOUGHTON, J.T., CALLANDER, B.A., and VARNEY, S.K., eds. 1992. Climate change 1992: The supplementary report to the IPCC scientific assessment. Cambridge: Cambridge University Press.

JACOBS, J., and STENTON, D. 1985. Environment, resources and prehistoric settlement in upper Frobisher Bay, Baffin Island. Arctic Anthropology 22(2):59-76.

JACOBY, G.C., and D'ARRIGO, R.D. 1989. Reconstructed Northern Hemisphere annual temperatures since 1671 based on high-latitude tree ring data from North America. Climatic Change 14:39-49.

KAMEDA, T., NARITA, H., SHOJI, H., NISHIO, F., and WATENABE, O. 1992. 450-year summer temperature record from melt feature profile in south Greenland ice core. In: 
Mikami, T., ed. Proceedings of the International Symposium on the Little Ice Age Climate. Tokyo: Department of Geography, Tokyo Metropolitan University. 101-107.

KAPLAN, S.A., and WOOLLETT, J.M. 2000. Challenges and choices: Exploring the interplay of climate, history and culture on Canada's Labrador coast. Arctic, Antarctic and Alpine Research 32(3):351-359.

KOERNER, R.M. 1977. Devon Island ice cap: Core stratigraphy and paleoclimate. Science 196:15-18.

KOERNER, R.M., and FISHER, D.A. 1990. A record of Holocene summer climate from a Canadian high-Arctic ice core. Nature 343(6259):630-631.

MacLAREN, I.A. 1958. The biology of the ringed seal (Phoca hispida schreber) in the eastern Canadian Arctic. Ottawa: Bulletin of the Fisheries Research Board of Canada.

. 1961. Methods of determining the numbers and availability of ringed seals in the Canadian Eastern Arctic. Arctic 14(3): $162-175$.

MAXWELL, M. 1985. Prehistory of the Eastern Arctic. New York: Academic Press.

McDONALD, M., ARRAGUTAINAQ, L., and NOVALINGA, Z. 1997. Voices from the bay: Traditional ecological knowledge of Inuit and Cree in the Hudson Bay bioregion. Ottawa: Canadian Arctic Resources Committee and the Environmental Committee of the Municipality of Sanikiluaq. 98 p.

McGHEE, R. 1969/70. Speculations on climate change and Thule culture development. Folk 11/12:173-184.

1972. Climate change and the development of Canadian Arctic cultural traditions. In: Vasari, Y., Hyvärinen, H., and Hicks, S., eds. Climatic changes in Arctic areas during the last ten thousand years. Oulu, Finland: Acta Universitatis Ouluensis, Ser. A. Geologica 1. 39-60.

. 1981. Archaeological evidence of climate change during the last 5000 years. In: Wigley, T., Ingram, M.J., and Farmer, G., ed. Climate and history: Studies in past climates and their impact on man. Cambridge: Cambridge University Press. 162-179.

McGOVERN, T. 1991. Climate, correlation, and causation in Norse Greenland. Arctic Anthropology 28(2):77-100.

MILLER, G.H., LOCKE, W.W., andLOCKE, G.W. 1980. Physical characteristics of the southeastern Baffin Island coastal zone. In: McCann, S.B., ed. The coastline of Canada: Littoral processes and shore morphology. 251-265.

OVERPECK, J., HUGHEN, K., HARDY, D., BRADLEY, R., CASE, R., DOUGLAS, M., FINNEY, B., GALEWSKI, K., JACOBY, G., JENNINGS, A., LAMOUREUX, S., LASCA, A., MACDONALD, G., MOORE, J., RETELLE, M., SMITH, S., WOLFE, A., and ZIELINSKI, G. 1997. Arctic environmental change over the last four centuries. Science 278:1251-1256.

SCHLEDERMANN, P. 1975. Thule Eskimo prehistory of Cumberland Sound, Baffin Island, Canada. Mercury Series,
Archaeological Survey of Canada Paper No. 38. Ottawa: National Museum of Man, National Museums of Canada.

1976. The effect of climatic/ecological changes on the style of Thule culture winter dwellings. Arctic and Alpine Research 8(1):37-47.

1980. Polynyas and prehistoric settlement patterns. Arctic 33(2):292-302.

SMITH, M., and RIGBY, B. 1981. Distribution of polynyas in the Canadian Arctic. In: Stirling, I., and Cleator, H., eds. Polynyas in the Canadian Arctic. Occasional Paper 45. Ottawa: Canadian Wildlife Service, Environment Canada. 7-28.

SMITH, T.G. 1973. Population dynamics of the ringed seal. Bulletin 181. Ottawa: Fisheries Research Board of Canada.

SMITH, T.G., HAMMILL, M.O., DOIDGE, D.W., CARTIER, T., and SLENO, G.A. 1979. Marine mammal studies in southeastern Baffin Island. Final Report to the Eastern Arctic Marine Environmental Studies (EAMES) Project. Canadian Manuscript Report of Fisheries and Aquatic Sciences No. 1552. Ste. Anne de Bellevue, Quebec: Arctic Biological Station, Canada Department of Fisheries and Oceans.

STENTON, D.R. 1989. Terrestrial adaptations of Neo-Eskimo coastal-marine hunters on southern Baffin Island, N.W.T. PhD. dissertation, Department of Anthropology, University of Alberta, Edmonton.

STENTON, D.R., and RIGBY, B.G. 1995. Community-based heritage education, training, and research: Preliminary report on the Tungatsivvik Archaeological Project. Arctic 48(1):47-56.

STEWART, R.E.A., STEWART B.E., STIRLING, I., and STREET, E. 1996. Counts of growth layer groups in cementum and dentine in ringed seals (Phoca hispida). Marine Mammal Science 12:383-401.

STIRLING, I. 1980. The biological importance of polynyas in the Canadian Arctic. Arctic 33(2):303-315.

- 1997. The importance of polynyas, ice edges, and leads to marine mammals and birds. Journal of Marine Systems 10: $9-21$.

STIRLING, I., CLEATOR, H., and SMITH, T.G. 1981. Marine mammals. In: Stirling, I., and Cleator, H., eds. Polynyas in the Canadian Arctic. Occasional Paper 45. Ottawa: Canadian Wildlife Service, Environment Canada. 45-58.

WILLIAMS, L.D. 1979. An energy balance model of potential glacierization on northern Canada. Arctic and Alpine Research 11:443-456.

WILLIAMS, L.D., and BRADLEY, R.S. 1985. Paleoclimatology of the Baffin Bay Region. In: Andrews, J.T., ed. Quaternary environments. Boston: Allen and Unwin. 741-773.

WOOLlETT, J., HENSHAW, A.S., and WAKE, C.P. 2000. Palaeoecological implications of archaeological seal bone assemblages: Case studies from Labrador and Baffin Island. Arctic 53(4):395-413. 